\title{
Fermentação da Proteína de Seis Alimentos por Microrganismos Ruminais, Incubados Puros ou com Monensina ou Rumensin ${ }^{\circledR, 1}$
}

\author{
Natália Guarino Souza Barbosa², Rogério de Paula Lana ${ }^{3}$, Antônio Bento Mâncio3, \\ Arnaldo Chaer Borges ${ }^{4}$, Augusto Cesar de Queiroz ${ }^{3}$, Juliana Silva Oliveira ${ }^{5}$
}

\begin{abstract}
RESUMO - Avaliaram-se os efeitos da fermentação in vitro de seis alimentos: fubá de milho (FM), farelo de soja (FS), farelo de trigo (FT), sorgo (SO), glúten de milho (GM) e uréia (UR), incubados puros ou com o antibiótico monensina, esse na forma pura para análise (Monensina) ou comercial (Rumensin ${ }^{\circledR}$ ). O experimento constituiu-se de 18 unidades experimentais [três alimentos energéticos ou protéicos $\times$ três tratamentos (controle, monensina ou rumensin) $\times$ duas repetições], em que foram analisados os parâmetros ruminais: $\mathrm{pH}$, produção de amônia $\left(\mathrm{NH}_{3}\right)$, proteína bacteriana $(\mathrm{PM})$, proteína solúvel (PS) e degradabilidade da proteína. As incubações foram feitas por 96 horas, em que as amostras foram coletadas às zero, 24, 48, 72 e 96 horas de fermentação. A leitura do $\mathrm{pH}$ foi realizada por um potenciômetro, enquanto as análises de amônia, proteínas microbiana e solúvel foram analisadas por técnicas colorimétricas. Não houve variações significativas no pH ao longo das incubações (6,94 inicial e 7,03 final). Não houve diferença entre as duas fontes de ionóforo testadas, contudo houve efeitos de interação entre antibiótico e alimento. A maior produção de $\mathrm{NH}_{3}$ nos alimentos protéicos foi encontrada para a UR, seguida do FS e GM, sendo reduzida na presença do ionóforo. A PS foi semelhante para os alimentos protéicos, aumentada pelo uso do ionóforo, exceto para a uréia. A PM decresceu para a UR e o FS, porém aumentou para o GM, sem ocorrer efeito de ionóforo. Nos alimentos energéticos a PM foi semelhante para os três alimentos e os ionóforos apenas reduziram a PM do SO. A maior produção de $\mathrm{NH}_{3}$ nos alimentos energéticos, foi encontrada para o FT, seguida do FM e SO. A PS foi semelhante para os alimentos energéticos. Houve correlações significativas das concentrações de $\mathrm{NH}_{3}$ com o $\mathrm{pH}$ final e $\% \mathrm{~PB}$ dos alimentos.
\end{abstract}

Palavras-chave: alimentos, amônia, fermentação, ionóforos, proteína, rúmen

\section{Protein Fermentation of Six Food Souces by Ruminal Microorganisms, Incubated Alone or With Monensin or Rumensin ${ }^{\circledR}$}

\begin{abstract}
The in vitro fermentation of the following food sources were evaluated: corn meal (CM), soybean meal (SM), wheat meaddlings (WM), sorghum (SO), corn gluten feed (CG) and urea (UR), incubated alone or with monensin, pure for analysis or comercial (Rumensin ${ }^{\circledR}$ ). The experiment constituted of 18 experimental units (three energetic or proteic food sources $\times$ three antibiotic (control, monensin or rumensin) $\times$ two duplicates), and the following fermentation parameters were analyzed: $\mathrm{pH}$, ammonia production, microbial protein, soluble protein and protein degradability. The incubations were developed in 96 hours and samples were collected at $0,24,48,72$ and 96 hours of fermentation. The pH was measured in glass electrode and ammonia, microbial protein and soluble protein by colorimetry. The was no $\mathrm{pH}$ variation along the incubations (initial $=6.94$ and final = 7.03). There was no difference between the two ionophore sources, but there was interactions between antibiotic and food sources. The greater ammonia production in the proteic sources was observed with UR, followed by SM and CG, being reduced by the ionophores. The soluble protein was similar for proteic food sources and increased by the ionophores, except for UR. The microbial protein decreased for UR and SM, but increased for CG, with no ionophore effect. In the energetic sources the ionophores only decreased microbial protein of SO. Greater ammonia production in the energetic sources was observed with WM, followed by CM and SO. The soluble protein and microbial protein were similar for all three food sources. Ammonia concentration in all incubations correlated with the final $\mathrm{pH}$ and $\% \mathrm{CP}$ of the food sources.
\end{abstract}

Key Words: ammonia, fermentation, food sources, ionophores, protein, rumen

\footnotetext{
1 Parte da tese de Mestrado do primeiro autor.

2 Estudante de Mestrado em Zootecnia - UFV - 36.571-000 - Viçosa - MG; Bolsista da CAPES.

3 Professor do Departamento de Zootecnia - UFV - 36.571-000 - Viçosa - MG; Bolsista do CNPq. E.mail: rlana@mail.ufv.br

4 Professor do Departamento de Microbiologia - UFV - 36.571-000 - Viçosa - MG.

5 Estudante de Zootecnia - UFV; Bolsista de Iniciação Científica - FAPEMIG.
} 


\section{Introdução}

A amônia é a principal fonte de nitrogênio usada para a síntese de proteína microbiana, sendo o produto final resultante do processo fermentativo de proteína realizado por microrganismos ruminais. Segundo SATTER e SLYTER (1974), as concentrações de N-NH3 superiores a $5 \mathrm{mg} / 100 \mathrm{~mL}$ de fluido representam um excesso que não é utilizado para a síntese microbiana. Segundo RUSSELL et al. (1992), a produção e absorção excessivas de amônia aumentam a excreção de $\mathrm{N}$ e o custo energético de produção de uréia. O excesso de amônia é excretado via urina e pode contaminar solos e cursos d'água próximos a centros criatórios (YECK et al.,1975; NOLAN et al., 1976).

A proteína solúvel é a fração correspondente aos aminoácidos e peptídeos solúveis, que são intermediários na produção de amônia. Segundo WALLACE et al. (1997), a hidrólise de proteínas por enzimas microbianas ruminais libera oligopeptídeos, quebrados em peptídeos menores até finalmente aminoácidos, para só então serem incorporados em proteína microbiana. Porém, quando há uma quebra excessiva de peptídeos, ultrapassando a capacidade de assimilação ocorre uma produção excessiva de amônia e uma pequena retenção de nitrogênio. A redução da quebra dos peptídeos reduziria o fluxo de nitrogênio protéico para amônia no rúmen ajudando a aumentar a eficiência da retenção do nitrogênio pelo animal (WALLACE et al., 1997). Um meio para inibir a quebra de peptídeos é a administração de ionóforos, cujos resultados in vitro causaram o acúmulo de peptídeos no flúido ruminal (WHETSTONE et al., 1981; NEWBOLD et al., 1990; WALLACE, 1992).

O uso do ionóforo monensina em animais não é recente. Seu início data da década de 70 , com o objetivo de aumentar a eficiência de utilização dos alimentos (GOODRICH et al., 1984; RUSSELL e STROBEL, 1989). A administração desse antibiótico visa, muitas vezes, apenas pequenos rendimentos em animais que consomem grandes quantidades de grãos, já que são esses os grandes produtores de carne ou leite, onde o mínimo lucro ou uma pequena economia na hora da aquisição do alimento, viabiliza a sua utilização.

A monensina diminui o crescimento de bactérias proteolíticas (HINO e RUSSELL, 1986) e também inibe a degradação de proteína hidrolisada e dietética (RUSSELL e MARTIN, 1984), sendo seu efeito maior na desaminação do que na proteólise. Inibem,

principalmente, as bactérias Gram-positivas, uma vez que a resistência está relacionada com a presença de uma membrana externa, de natureza lipopolissacarídica, existente em bactérias Gram-negativas (RUSSELL e STROBEL, 1989). Podem reduzir a produção de amônia no rúmen, mas este efeito ainda foi pouco explicado. Os efeitos são mais drásticos em dietas à base de forragem pois, sob estas condições, a taxa de degradação de proteína é muito maior do que a taxa de fermentação de carboidrato e os níveis de amônia ruminal geralmente são altos (RUSSELL, 1996).

Objetivou-se avaliar a fermentação da proteína de seis alimentos: fubá de milho (FM), farelo de soja (FS), farelo de trigo (FT), glúten de milho (GM), sorgo (S) e uréia (Ur), com ou sem a administração do antibiótico monensina em sua forma pura para análise (monensina) ou comercial (rumensin $\AA$ ). Objetivou-se, ainda, avaliar uma nova técnica de determinação in vitro da degradabilidade da proteína dos alimentos.

\section{Material e Métodos}

\section{Local, animal e alimentação}

O experimento foi conduzido no Laboratório de Microbiologia de Anaeróbios, Departamento de Microbiologia da Universidade Federal de Viçosa (UFV), Viçosa, Minas Gerais.

Foi utilizado o líquido de rúmen de um novilho fistulado no rúmen, alimentado com capim verde picado, uma vez ao dia, pela manhã. $\mathrm{O}$ animal foi alojado no Laboratório de Animais do Departamento de Zootecnia da UFV.

Coleta, processamento do líquido de rúmen e preparo do meio de cultura

Coletaram-se $500 \mathrm{~mL}$ de líquido ruminal com $\mathrm{pH}$ em torno da neutralidade, duas horas após o arraçoamento. O líquido ruminal foi filtrado em quatro camadas de gaze, acondicionando em garrafa térmica com fechamento hermético e transportado imediatamente para o laboratório, onde foi centrifugado em anaerobiose, a $3000 \mathrm{rpm}$, em uma temperatura de $25^{\circ} \mathrm{C}$ por três minutos, para que ocorresse a sedimentação de partículas de alimentos e protozoários. O sobrenadante foi transferido para outro tubo e novamente centrifugado a $6000 \mathrm{rpm}$ por cinco minutos, onde o sedimento foi ressuspenso em $200 \mathrm{ml}$ de solução tampão "McDougall", sendo utilizado nas incubações. A solução tampão de McDougall constituiu-se de 9,80 g/L de NaHCO3; 7,0 g/L de 
1318 Rev. bras. zootec.

$\mathrm{Na}_{2} \mathrm{HPO}_{4} * 7 \mathrm{H}_{2} \mathrm{O} ; 0,57 \mathrm{~g} / \mathrm{L} \mathrm{KCl} ; 0,47 \mathrm{~g} / \mathrm{L}$ de NaCl ; $0,12 \mathrm{~g} / \mathrm{L}$ de $\mathrm{MgSO}_{4} * 7 \mathrm{H}_{2} \mathrm{O} ; 0,05 \mathrm{~g} / \mathrm{L}$ de $\mathrm{CaCl}_{2} * 2 \mathrm{H}_{2} \mathrm{O}$ completados até um volume de $1000 \mathrm{~mL}$ com água destilada.

Produção de amônia, proteína solúvel e proteína microbiana em função da fonte de alimentos e monensina

Foram testadas três fontes energéticas (fubá de milho, farelo de trigo e sorgo) e três fontes protéicas (farelo de soja, glúten de milho e uréia), puros ou em combinação com o ionóforo monensina puro para análise ou na forma comercial (Rumensin ${ }^{\circledR}$ ). Os teores de proteína bruta dos alimentos foram de 45,6; 9,$2 ; 13,7 ; 9,4 ; 64,4 ;$ e $254,6 \%$ para farelo de soja, fubá de milho, farelo de trigo, sorgo, glúten de milho e uréia, respectivamente.

As incubações foram realizadas em tubos Vacumtainer® de $15 \mathrm{~mL}$, hermeticamente fechados, contendo $9,8 \mathrm{ml}$ da cultura e $100 \mathrm{mg}$ dos alimentos. Foi adicionado $0,2 \mathrm{~mL}$ de etanol contendo ou não o ionóforo diluído, de modo que a concentração final do mesmo no meio de cultura atingisse o valor de $5,0 \mathrm{mM}$, conforme observado in vivo ao se utilizar a dosagem recomendada do produto comercial. Os tubos foram saturados com dióxido de carbono e incubados a $39^{\circ} \mathrm{C}$, em banho-maria, por 96 horas.

Coletaram-se amostras de $0,6 \mathrm{~mL}$ do material incubado para a determinação de amônia, proteína microbiana e proteína solúvel nos tempos zero, 24, 48, 72 e 96 horas após o início da fermentação. $\mathrm{O}$ pH foi medido no início e no final do período de incubação (zero e 96 horas). As alíquotas foram coletadas por intermédio de seringas, para que houvesse a manutenção da anaerobiose dentro dos tubos.

As amostras foram centrifugadas em tubo eppendorf de $1,5 \mathrm{~mL}$ a $12.000 \mathrm{rpm}$ por $10 \mathrm{~min}$, onde o sobrenadante foi transferido para um novo tubo eppendorf e congelado para posterior análise de amônia e proteína solúvel (peptídeos e aminoácidos). A análise de amônia foi feita pelo método colorimétrico de CHANEY e MARBACH (1962) e de proteína solúvel pelo método de LOWRY et al. (1951).

Os sedimentos resultantes do processo anterior foram ressuspensos em solução salina $(0,9 \%$ de $\mathrm{NaCl}$ ) e centrifugados a $12.000 \mathrm{rpm}$ por $10 \mathrm{~min}$, duas vezes consecutivas. Finalmente, foram ressuspensos com água destilada até o volume de 0,6 mL, homogeneizados e congelados para posterior análise de proteína microbiana, por intermédio do método de LOWRY et al. (1951).

\section{Degradabilidade da proteína dos alimentos}

Para estimar a degradabilidade da proteína (DP), determinou-se o nitrogênio utilizado na produção de amônia, proteína solúvel e crescimento microbiano em 96 horas de incubação, dividido pela quantidade de nitrogênio do alimento, conforme a seguinte fórmula:

$D P(\%)=\frac{N-N_{3}+N-\text { proteína solúvel }+N-\text { proteína microbiana }}{N-\text { alim ento }} \times 100$ em que: $\mathrm{N}-\mathrm{NH}_{3}=$ nitrogênio $(\mathrm{mg})$ utilizado na produção de amônia; $\mathrm{N}$-proteína solúvel = nitrogênio (mg) na forma de proteína solúvel, peptídeos e aminoácidos; $\mathrm{N}$-proteína microbiana $=$ nitrogênio (mg) utilizado na síntese de proteína microbiana; $\mathrm{N}$-alimento = nitrogênio $(\mathrm{mg})$ presente no alimento.

As quantidades de nitrogênio presentes na amônia, proteína solúvel, proteína microbiana e alimentos, foram calculadas com o uso das seguintes fórmulas: $m g \mathrm{~N}-\mathrm{NH}_{3}=\left(\Delta \mathrm{NH}_{3}[96-\right.$ Oh] $\times 14) / 100$

$m g N$ - proteína solúvel $=(\Delta$ proteína solúvel $[96-0 h]) /(6,25 x 100)$ $m g N$ - proteína microbiana $=(\Delta$ proteína microbiana $[96-0 h])$ $(6,25 \times 100)$

$m g \mathrm{~N}$-alimento $=($ alimento $[\mathrm{mg}] x$ proteína bruta $[\% / 100]) / 6,25$ em que: $\Delta \mathrm{NH}_{3}(96-0 \mathrm{~h})=$ concentração final - concentração inicial de amônia, em mmol/1000 mL ou $\mathrm{mM} ; 14=$ peso atômico do nitrogênio; $100=1.000 / 10$ $\mathrm{mL}$ de líquido de rúmen; $\Delta$ Proteína solúvel $(96-0 \mathrm{~h})=$ concentração final - concentração inicial de proteína solúvel, em mg/L; 6,25 = relação proteína:N; $\Delta$ Proteína microbiana $(96-0 \mathrm{~h})=$ concentração final - concentração inicial de proteína microbiana, em mg/L.

Oexperimento foi analisado em delineamento inteiramente casualizadoem dois fatoriais $3 \times 3 \times 2$ (três alimentos energéticos ou três protéicos; ausência ou presença de monensina ou Rumensin $\AA^{\circledR}$; e duas repetições), totalizando 18 unidades experimentais em cada um dos fatoriais. As análises estatísticas foram realizadas utilizando o procedimento ANOVA e correlações lineares do programa estatístico Minitab (RYAN e JOINER, 1994). Aplicou-se o teste Tukey, a 5\% de probabilidade, para comparações entre médias significativas. As taxas de produção de amônia foramobtidas pela derivada primeira das equações de regressão polinomial, utilizando-se o tempo em que a derivada segunda igualava-se a zero.

\section{Resultados e Discussão}

De modo geral, não houve grande variação no $\mathrm{pH}$ ao longo das incubações, observando-se pH médio inicial de 6,94 e final de 7,03. Entretanto, quando se utilizou a uréia, o pH médio inicial foi de 7,47 e o final, de 8,97. 
BARBOSA et al.

As curvas de produção de amônia, proteína solúvel e proteína microbiana dos alimentos energéticos e protéicos, independentemente da presença ou não de antibióticos, encontram-se na Figura 1. Observouse taxas de produção de amônia de 4,20; 3,72; 3,86; 2,$64 ; 5,58$ e $8,31 \% / h$ para o fubá de milho, farelo de soja, farelo de trigo, glúten de milho, sorgo e uréia, respectivamente. Verifica-se que os parâmetros avaliados atingiram o platô entre 24 e 48 horas. Portanto, optou-se por fazer as análises estatísticas dos efeitos de tratamentos às 48 horas de incubação para os alimentos energéticos e protéicos, separadamente, para facilitar a interpretação dos dados.

De modo geral, não houve diferença entre as fontes de antibiótico testadas (Monensina versus Rumensin $\left.{ }^{\circledR}\right)$. Portanto, o produto comercial demonstrou-se eficiente em alterar os parâmetros de fermentação avaliados. Houve interação entre antibióticos e alimentos protéicos sobre a produção de amônia e proteína solúvel e entre antibióticos e alimentos energéticos sobre a proteína microbiana $(\mathrm{P}<0,01)$ (Tabela 1). A produção de amônia foi maior
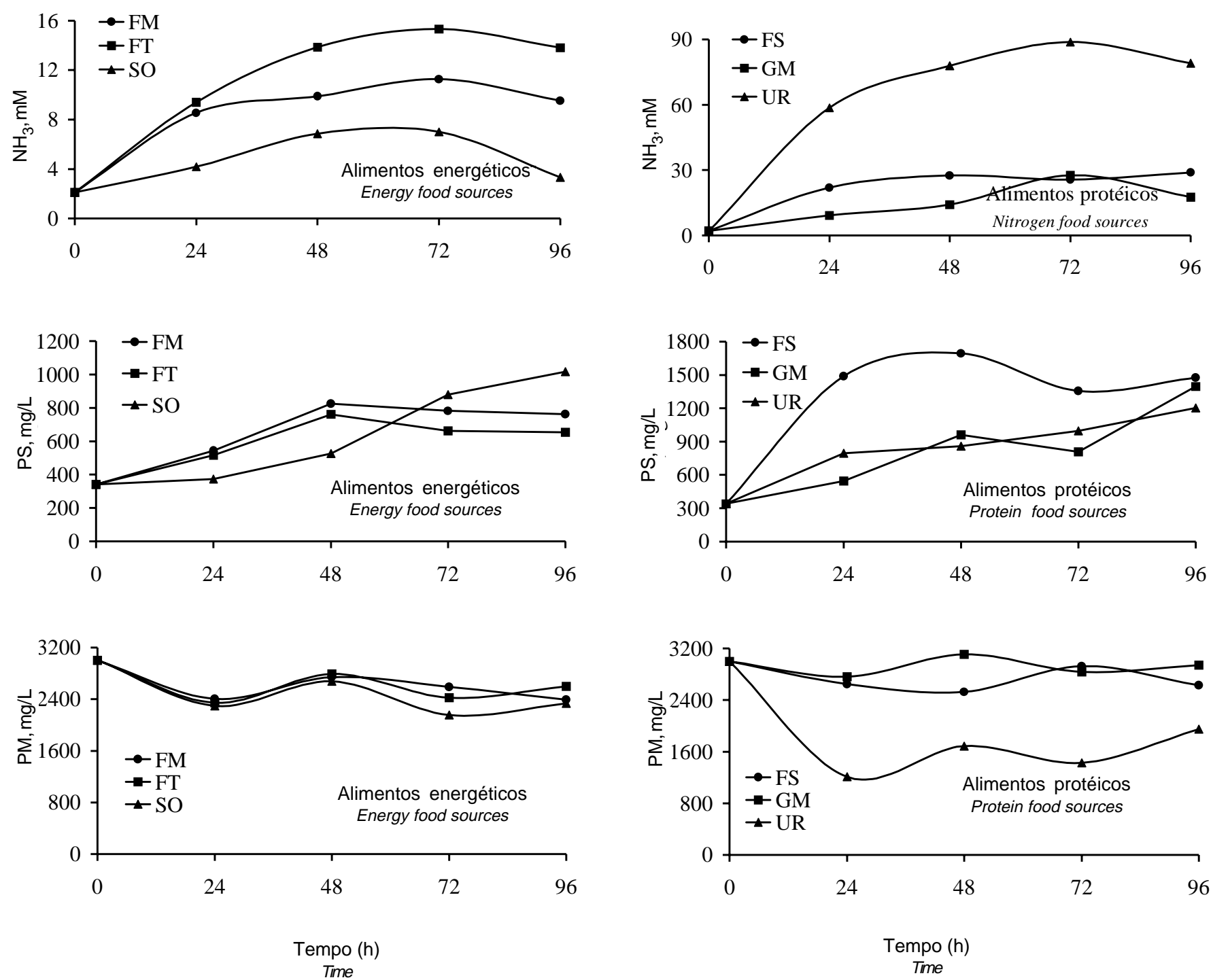

Figura 1 - Curvas de produção de amônia $\left(\mathrm{NH}_{3}\right)$, proteína solúvel (PS) e proteína microbiana (PM), provenientes da fermentação de alimentos energéticos (fubá de milho, FM; farelo de trigo, FT; e sorgo, SO) e alimentos protéicos (farelo de soja, FS; glúten de milho, GM; e uréia, UR) por microrganismos ruminais em função do tempo de incubação. Cada ponto corresponde à média de seis observações.

Figure 1 - Curves of ammonia production $\left(\mathrm{NH}_{3}\right)$, soluble protein $(P S)$ and microbial protein (PM), from fermentation of energetic food sources (corn meal, FM; wheat meaddlings, FT; and sorghum, SO) and proteic food sources (soybean meal, FS; corn gluten meal, GM; and urea, UR) by rumen microorganisms as a function of time of incubation. Each point is the mean of six observations. 
1320 Rev. bras. zootec.

Tabela 1 - Diferencial de concentração de amônia $\left(\mathrm{NH}_{3}\right)$, proteína solúvel (PS) e proteína microbiana (PM) em 48 horas de fermentação in vitro dos alimentos por microrganismos ruminais, em função de fontes de alimentos e ionóforos (monensina ou rumensin, M/R)

Table 1 - Diferential concentration of ammonia $\left(\mathrm{NH}_{3}\right)$, soluble protein (PS) and microbial protein (PM) in 48 hours fermentation in vitro of food sources by rumen microorganisms, as a function of food sources and ionophores (monensin or rumensin, $M / R$ )

\begin{tabular}{|c|c|c|c|c|}
\hline & \multicolumn{3}{|c|}{$\begin{array}{l}\text { Amônia }\left(\mathrm{NH}_{3}, \mathrm{mM}\right) \text { - alimentos protéicos } \\
\text { Ammonia }\left(\mathrm{NH}_{3}, \mathrm{mM}\right) \text { - proteic food sources }\end{array}$} & \multirow[b]{2}{*}{$\begin{array}{l}\mathrm{EP} \\
S E\end{array}$} \\
\hline & $\begin{array}{c}\text { Farelo de soja } \\
\text { Soybean meal }\end{array}$ & $\begin{array}{l}\text { Glúten de milho } \\
\text { Corn gluten meal }\end{array}$ & $\begin{array}{l}\text { Uréia } \\
\text { Urea }\end{array}$ & \\
\hline $\begin{array}{l}\mathrm{M} / \mathrm{R}-\text { não (no) } \\
\operatorname{sim}(\text { yes }) \\
\mathrm{EP}(S E)\end{array}$ & $\begin{array}{c}26,7^{\mathrm{bA}} \\
24,8^{\mathrm{bA}} \\
1,6\end{array}$ & $\begin{array}{c}17,5^{\mathrm{aB}} \\
9,5^{\mathrm{aA}} \\
1,6\end{array}$ & $\begin{array}{c}84,5^{\mathrm{cB}} \\
71,4^{\mathrm{cA}} \\
1,6\end{array}$ & $\begin{array}{l}1,95 \\
1,38\end{array}$ \\
\hline \multirow{2}{*}{$\operatorname{EP}(S E)$} & \multicolumn{3}{|c|}{$\begin{array}{l}\text { Proteína solúvel }(\mathrm{mg} / \mathrm{L}) \text { - alimentos protéicos } \\
\text { Soluble protein }(\mathrm{mg} / \mathrm{L}) \text { - proteic food sources }\end{array}$} & \\
\hline & $\begin{array}{c}\text { Farelo de soja } \\
\text { Soybean meal }\end{array}$ & $\begin{array}{l}\text { Glúten de milho } \\
\text { Corn gluten meal }\end{array}$ & $\begin{array}{l}\text { Uréia } \\
\text { Urea }\end{array}$ & \\
\hline $\begin{array}{r}\mathrm{M} / \mathrm{R}-\operatorname{não}(\text { no) } \\
\operatorname{sim}(\text { yes }) \\
\mathrm{EP}\end{array}$ & $\begin{array}{c}660^{\mathrm{aA}} \\
1701^{\mathrm{bB}} \\
73,33\end{array}$ & $\begin{array}{l}359^{\mathrm{aA}} \\
749^{\mathrm{aB}} \\
73,33\end{array}$ & $\begin{array}{l}485^{\mathrm{aA}} \\
535^{\mathrm{aA}} \\
73,33\end{array}$ & $\begin{array}{l}89,81 \\
63,50\end{array}$ \\
\hline \multirow{2}{*}{$\mathrm{EP}$} & \multicolumn{3}{|c|}{$\begin{array}{l}\text { Proteína microbiana }(\mathrm{mg} / \mathrm{L}) \text { - alimentos energéticos } \\
\text { Microbial protein }(\mathrm{mg} / \mathrm{L}) \text { - energetic food sources }\end{array}$} & \\
\hline & $\begin{array}{l}\text { Fubá de milho } \\
\text { Corn meal }\end{array}$ & $\begin{array}{l}\text { Farelo de trigo } \\
\text { Wheat meaddlings }\end{array}$ & $\begin{array}{l}\text { Sorgo } \\
\text { Sorgum }\end{array}$ & \\
\hline $\begin{array}{r}\mathrm{M} / \mathrm{R}-\mathrm{não}(\text { no) } \\
\operatorname{sim}(\text { yes })\end{array}$ & $\begin{array}{l}-250^{\mathrm{aA}} \\
-265^{\mathrm{aA}}\end{array}$ & $\begin{array}{c}95^{\mathrm{aA}} \\
-362^{\mathrm{aA}}\end{array}$ & $\begin{array}{r}687^{\mathrm{aA}} \\
-832^{\mathrm{aB}}\end{array}$ & $\begin{array}{l}270,30 \\
191,10\end{array}$ \\
\hline EP & 220,7 & 220,7 & 220,7 & \\
\hline
\end{tabular}

Letras minúsculas (em fontes de alimentos) e letras maiúsculas (em adição de antibiótico), seguidas por letras iguais, não diferem pelo teste de Tukey $(P>0,05)$.

Small letters (for food sources) and capital letters (for antibiotic addition), followed by same letters do not differ by Tukey test ( $P>0.05)$.

pelo uso da uréia, seguida do farelo de soja e glúten de milho, sendo reduzida pelos antibióticos, exceto no farelo de soja.

CUNHA (1999) observou que a produção de amônia nos alimentos testados apresentava correlação com a degradabilidade da proteína dos mesmos, ou seja, quanto maior a degradabilidade, maior foi a produção de amônia. Neste trabalho, observa-se a mesma tendência, uma vez que a uréia proporcionou maior produção de amônia, seguida do farelo de soja e glúten de milho. O efeito da monensina na redução da produção de amônia foi reportado anteriormente em estudos in vitro (VAN NEVEL e DEMEYER, 1977; RUSSELL e MARTIN, 1984) e in vivo (DINIUS et al., 1976; LANA e RUSSELL, 1997). Esse trabalho demonstrou a inibição da produção de amônia pela hidrólise da uréia.

A concentração de proteína solúvel foi similar para os três alimentos protéicos, sendo aumentada pelos antibióticos, exceto na uréia. A síntese de proteína microbiana foi similar para os três alimentos energéticos, sendo diminuída pelos antibióticos, quando o sorgo foi utilizado (Tabela 1). Uma vez que os ionóforos inibem a população microbiana com alta capacidade de desaminação de aminoácidos (RUSSELL et al., 1988; CHEN e RUSSELL, 1989), é justificável que ocorra acúmulo de peptídeos e proteína solúvel no meio de cultura. Neste caso, há maior fluxo de aminoácidos para ser utilizado pelo ruminante em nível de intestino delgado.

A concentração de proteína microbiana no meio de cultura, durante as 48 horas de incubação dos alimentos protéicos, decresceu com o uso de uréia e farelo de soja e cresceu com o glúten de milho (Tabela 2), provavelmente devido à maior disponibilidade energética do glúten e à falta de peptídeos no caso da uréia. A produção de amônia na incubação dos alimentos energéticos foi maior para o farelo de trigo e fubá de milho e menor para o sorgo (Tabela 2), o que provavelmente está relacionado à degradabilidade da proteína, conforme verificado para os alimentos protéicos. Não houve efeito das fontes de alimento energéticos sobre a proteína solúvel e da presença de antibióticos nos três parâmetros avaliados $(\mathrm{P}>0,05)$ (Tabela 2).

$\mathrm{O}$ fator que mais afetou a concentração da prote- 
BARBOSA et al.

Tabela 2 - Diferencial de concentração de amônia $\left(\mathrm{NH}_{3}\right)$, proteína solúvel (PS) e proteína microbiana (PM) em 48 horas de fermentação in vitro dos alimentos por microrganismos ruminais, em função de fontes de alimento

Table 2 - Diferential concentration of ammonia $\left(\mathrm{NH}_{3}\right)$, soluble protein (PS) and microbial protein (PM) in 48 hours fermentation in vitro of food sources by rumen microorganisms, in function of food sources

\begin{tabular}{|c|c|c|c|c|}
\hline & \multicolumn{3}{|c|}{$\begin{array}{l}\text { Alimentos energéticos } \\
\text { Energetic food sources }\end{array}$} & \multirow[b]{2}{*}{$\begin{array}{l}\mathrm{EP} \\
S E\end{array}$} \\
\hline & $\begin{array}{c}\text { Fubá de milho } \\
\text { Corn meal }\end{array}$ & $\begin{array}{c}\text { Farelo de trigo } \\
\text { Wheat meaddlings }\end{array}$ & $\begin{array}{c}\text { Sorgo } \\
\text { Sorghum }\end{array}$ & \\
\hline $\begin{array}{l}\mathrm{NH}_{3}, \mathrm{mM} \\
\mathrm{PS}, \mathrm{mg} / \mathrm{L}\end{array}$ & $\begin{array}{l}7,79^{a b} \\
485^{a} \\
\end{array}$ & $\begin{array}{l}11,75^{\mathrm{b}} \\
421^{\mathrm{a}} \\
\end{array}$ & $\begin{array}{r}4,76^{\mathrm{a}} \\
187^{\mathrm{a}} \\
\end{array}$ & $\begin{array}{r}1,627 \\
83,799 \\
\end{array}$ \\
\hline \multirow{2}{*}{$\underline{\mathrm{PS}, \mathrm{mg} / \mathrm{L}}$} & & $\begin{array}{l}\text { limentos protéico } \\
\text { Proteic food sources }\end{array}$ & & \\
\hline & $\begin{array}{c}\text { Farelo de soja } \\
\text { Soybean meal }\end{array}$ & $\begin{array}{l}\text { Glúten de milho } \\
\text { Corn gluten meal }\end{array}$ & $\begin{array}{l}\text { Uréia } \\
\text { Urea }\end{array}$ & \\
\hline$\overline{\mathrm{PM}, \mathrm{mg} / \mathrm{L}}$ & $-473^{b}$ & $109^{c}$ & $-1311^{a}$ & 186,56 \\
\hline
\end{tabular}

Médias seguidas por letras iguais não diferem pelo teste de Tukey $(P>0,05)$.

Means followed by same letters do not differ by Tukey test $(P>05)$.

ína solúvel durante as incubações dos alimentos protéicos foi a fonte de alimento $(\mathrm{r}=-0,68)$ (Tabela 3$)$, em que a uréia apresentou a menor concentração da mesma, uma vez que a uréia contém apenas nitrogênio não protéico. A correlação negativa do $\mathrm{pH}$ final e \% PB sobre a proteína solúvel deve-se ao fato de a uréia ter elevado o pH do meio de incubação e à maior quantidade de nitrogênio incubado pelo uso da mesma.

As concentrações de amônia e proteína microbiana foram altamente correlacionadas com o pH final, \% PB e fonte de alimento, havendo menor correlação com a presença de antibióticos (Tabela 3). No caso da amônia e conforme relatado para a proteína solúvel, estes efeitos foram atríbuídos à presença da uréia, que elevou o pH do meio, e à maior quantidade de nitrogênio incubado. Em relação à proteína microbiana, devido à falta de peptídeos e fonte de energia na uréia, não houve estímulo à síntese de proteína microbiana.
Embora o efeito do $\mathrm{pH}$ sobre a produção de amônia tenha sido confundido pelo uso da uréia, trabalhos anteriores também verificaram alta correlação entre o pH do meio e a produção de amônia em fontes de proteína verdadeira (LANA et al., 1998; CUNHA et al., 2000). O pH não foi influenciado pelo uso de monensina ou rumensin ${ }^{\circledR}$, o que contrasta com dados encontrados por DOMESCIK e MARTIN (1997), que obtiveram valores mais elevados de $\mathrm{pH}$ pelo uso de monensina e laidlomicina em um experimento in vitro, analisando milho, tripticase e alfafa.

$\mathrm{O}$ fator que mais afetou a concentração da proteína solúvel durante as incubações dos alimentos energéticos foi a fonte de alimento $(r=-0,56)$ (Tabela 4), conforme observado para os alimentos protéicos. A concentração de proteína microbiana, por sua vez, correlacionou negativamente com a presença de antibióticos. A amônia correlacionou positivamente com o $\mathrm{pH}$ final,

Tabela 3 - Correlações entre pH final, proteína bruta (\%PB), alimentos, antibiótico, amônia $\left(\mathrm{NH}_{3}\right)$, proteína solúvel (PS) e proteína microbiana (PM) em 48 horas de fermentação in vitro dos alimentos protéicos por microrganismos ruminais

Table 3 - Correlations among final $\mathrm{pH}$, crude protein (\% CP), food sources, antibiotic, ammonia $\left(\mathrm{NH}_{3}\right)$, soluble protein (PS) and microbial protein $(P M)$ in 48 hours in vitro fermentation of proteic food sources by rumen microorganisms

\begin{tabular}{lcccccc}
\hline $\begin{array}{l}\text { Alimentos protéicos } \\
\text { Proteic food sources }\end{array}$ & $\begin{array}{c}\mathrm{pH} \text { final } \\
\text { Final } \mathrm{pH}\end{array}$ & $\begin{array}{l}\% \mathrm{~PB} \\
\% C P\end{array}$ & $\begin{array}{c}\text { Alimento } \\
\text { Food source }\end{array}$ & $\begin{array}{c}\text { Antibiótico } \\
\text { Antibiotic }\end{array}$ & $\begin{array}{c}\mathrm{NH}_{3} \\
(48 \mathrm{~h}, \mathrm{mM})\end{array}$ & $\begin{array}{c}\mathrm{PS} \\
(48 \mathrm{~h}, \mathrm{mg} / \mathrm{L})\end{array}$ \\
\hline \%PB $(\% \mathrm{CP})$ & $0,99^{* *}$ & & & & & \\
Alimento $($ food source) & $0,89^{* *}$ & $0,90^{* *}$ & & & & \\
Antibiótico (antibiotic) & 0,002 & 0,00 & 0,00 & & \\
$\mathrm{NH}_{3}(48 \mathrm{~h}, \mathrm{mM})$ & $0,94^{* *}$ & $0,95^{* *}$ & $0,74^{* *}$ & $-0,13$ & $-0,34$ & $-0,78^{* *}$ \\
$\mathrm{PS}(48 \mathrm{~h}, \mathrm{mg} / \mathrm{L})$ & $-0,48^{*}$ & $-0,49^{*}$ & $-0,68^{* *}$ & $0,49 *$ & $-0,025$ \\
PM $(48 \mathrm{~h}, \mathrm{mg} / \mathrm{L})$ & $-0,73^{* *}$ & $-0,72^{* *}$ & $-0,48^{*}$ & $-0,083$ & $-0,73$ \\
\hline
\end{tabular}

** $e^{*}$ Significativos a 1 e $5 \%$ de probabilidade.

${ }^{* *}$ and ${ }^{*}$ Significant at 1 and $5 \%$ probability. 
1322 Rev. bras. zootec.

Tabela 4 - Correlações entre pH final, proteína bruta (\%PB), alimentos, antibiótico, amônia $\left(\mathrm{NH}_{3}\right)$, proteína solúvel (PS) e proteína microbiana (PM) em 48 horas de fermentação in vitro dos alimentos energéticos por microrganismos ruminais

Table 4 - Correlations among final $\mathrm{pH}$, crude protein (\%CP), food sources, antibiotic, ammonia $\left(\mathrm{NH}_{3}\right)$, soluble protein (PS) and microbial protein (PM) in 48 hours in vitro fermentation of energetic food sources by rumen microorganisms

\begin{tabular}{|c|c|c|c|c|c|c|}
\hline $\begin{array}{l}\text { Alimentos energéticos } \\
\text { Energetic food sources }\end{array}$ & $\begin{array}{l}\mathrm{pH} \text { final } \\
\text { Final } \mathrm{pH}\end{array}$ & $\begin{array}{l}\% \mathrm{~PB} \\
\% C P\end{array}$ & $\begin{array}{l}\text { Alimento } \\
\text { Food source }\end{array}$ & $\begin{array}{c}\text { Antibiótico } \\
\text { Antibiotic }\end{array}$ & $\begin{array}{c}\mathrm{NH}_{3} \\
(48 \mathrm{~h}, \mathrm{mM})\end{array}$ & $\begin{array}{c}\text { PS } \\
(48 \mathrm{~h}, \mathrm{mg} / \mathrm{L})\end{array}$ \\
\hline$\% \mathrm{~PB}(\% C P)$ & 0,45 & & & & & \\
\hline Alimento (food source) & $-0,05$ & 0,04 & & & & \\
\hline Antibiótico (antibiotic) & 0,03 & 0,00 & 0,00 & & & \\
\hline $\mathrm{NH}_{3}(48 \mathrm{~h}, \mathrm{mM})$ & $0,59 * *$ & $0,50 *$ & $-0,24$ & $0,51 *$ & & \\
\hline PS (48 h, mg/L) & 0,45 & 0,16 & $-0,56 *$ & $-0,21$ & 0,21 & \\
\hline $\mathrm{PM}(48 \mathrm{~h}, \mathrm{mg} / \mathrm{L})$ & 0,15 & 0,07 & $-0,05$ & $-0,58 *$ & $0,66 * *$ & $-0,22$ \\
\hline
\end{tabular}

${ }^{* *} \mathrm{e}^{*}$ Significativos a 1 e $5 \%$ de probabilidade.

${ }^{* *}$ and ${ }^{*}$ Significant at 1 and $5 \%$ probability.
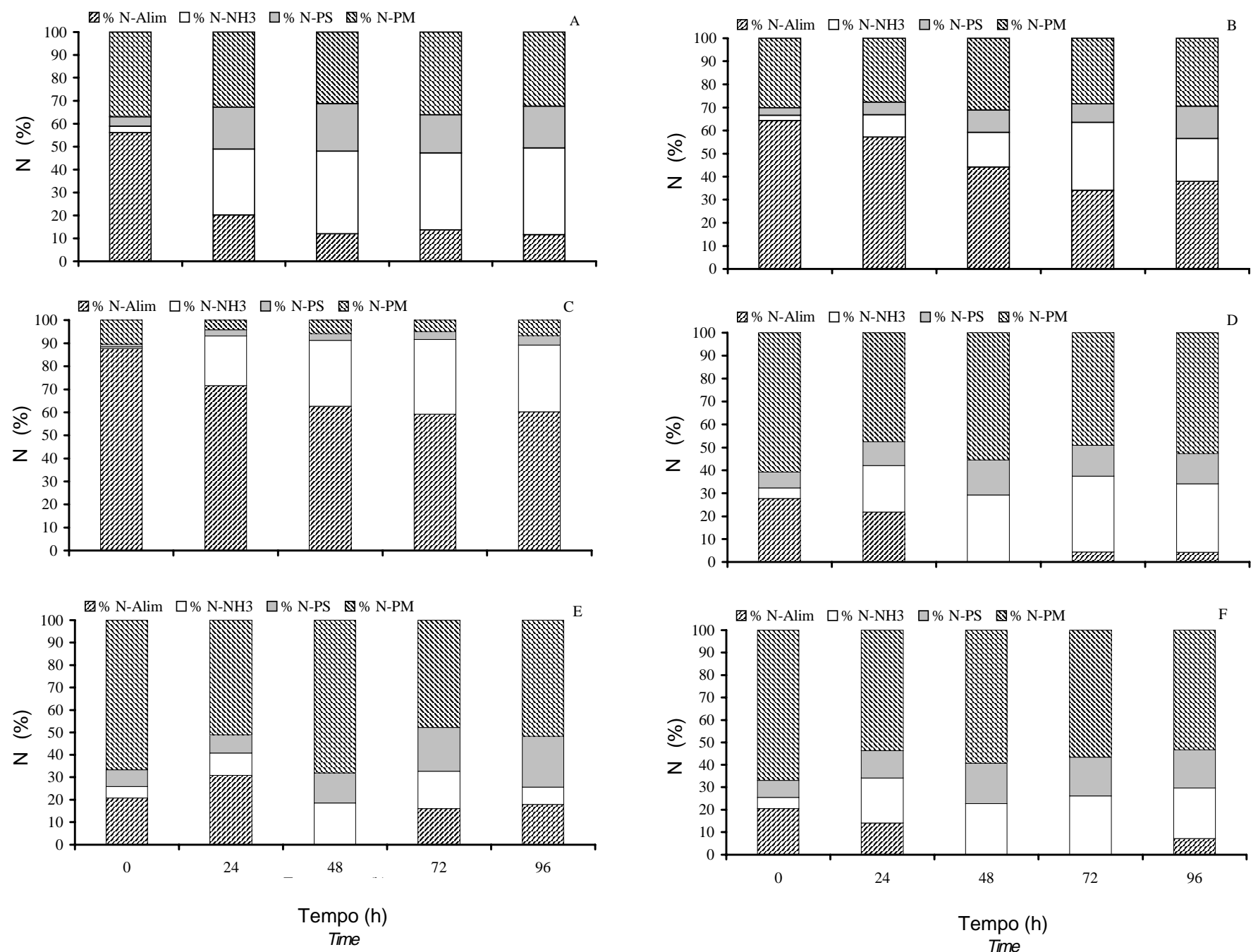

Figura 2 - Frações do nitrogênio presente nos alimentos (N-Alim), amônia ( $\mathrm{N}-\mathrm{NH}_{3}$ ), proteína solúvel (N-PS) ou proteína microbiana (N-PM) ao longo das fermentações dos alimentos (farelo de soja, A; glúten de milho, B; uréia, C; farelo de trigo, D; sorgo, E; e fubá de milho, F) por microrganismos ruminais.

Figure 2 - Nitrogen fractions as food $\left(\mathrm{N}\right.$-Alim), ammonia $\left(\mathrm{N}-\mathrm{NH}_{3}\right)$, soluble protein $(\mathrm{N}-\mathrm{PS})$ or microbial protein $(\mathrm{N}-\mathrm{PM})$ over fermentation of food sources (soybean meal, $A$; corn gluten meal, B; urea, $C$; wheat meaddlings, $D$; sorghum meal, E; and corn meal, F) by rumen microorganisms. 
\% PB e proteína microbiana e negativamente com a presença de antibióticos. Todos estes resultados são esperados, uma vez que o pH inibe a produção de amônia (ERFLE et al., 1982; LANA et al., 1998), a maior quantidade de proteína bruta estimula maior produção de amônia, a maior população microbiana aumenta o potencial de produção de amônia e os antibióticos inibem a população bacteriana com alta produção de amônia (RUSSELL et al., 1988; CHEN e RUSSELL, 1989).

Constam da Figura 2 histogramas das proporções de nitrogênio ao longo da incubação presente nas frações de amônia, proteína solúvel, proteína microbiana e proteína do alimento, sendo que o último foi calculado pela diferença das demais frações, a partir das 24 horas. Observa-se que a maior parte do nitrogênio nas incubações está retida na proteína microbiana, devido ao uso de inóculo contendo alta

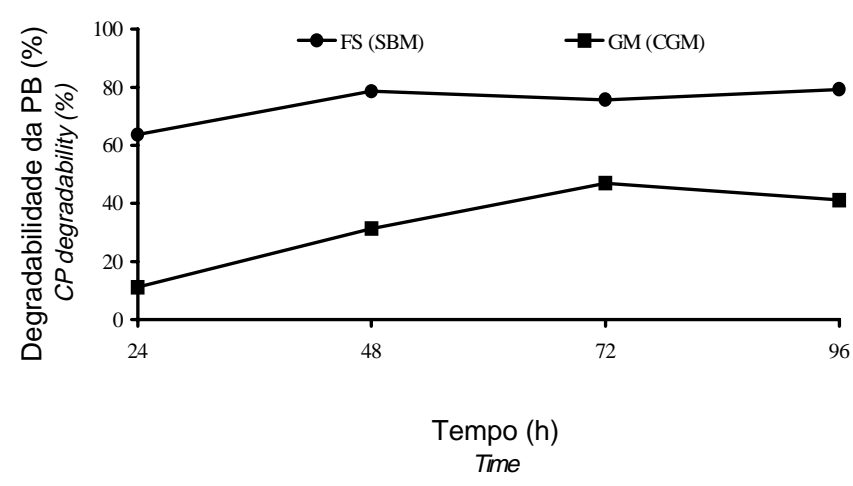

Figura 3 - Degradabilidade da proteína dos alimentos protéicos (farelo de soja, FS; e glúten de milho, GM) ao longo do tempo de incubação.

Figure 3 - Protein degradabillity of proteic food sources (soybean meal, SBM; and corn gluten meal, CGM) along the incubation.

concentração de microrganismos, que foi obtido pela centrifugação do líquido de rúmen e resuspensão do sedimentos em um menor volume final do meio.

Devido à baixa quantidade de proteína dos alimentos energéticos ao início da incubação, não foram obtidos valores confiáveis de degradabilidade da mesma $\left(\left(\left(\mathrm{N}-\mathrm{NH}_{3}+\mathrm{N}\right.\right.\right.$-peptídeos $+\mathrm{N}$-microrganismos) $/ \mathrm{N}$-alimento $* 100)$. Entretanto, os alimentos protéicos (farelo de soja e glúten de milho) apresentaram menor proporção de nitrogênio microbiano, permitindo obter valores mais confiáveis de degradabilidade, conforme pode ser observado na Figura 3. Os alimentos protéicos atingiram valores máximos de degradabilidade às 48 horas, em que o farelo de soja apresentou degradabilidade em torno de $60 \%$ e o glúten de milho, de $35 \%$. Pelos resultados obtidos com os alimentos energéticos, sugere-se utilizar maior quantidade de alimento na incubação e diluir o líquido de rúmen com o meio de cultura, para reduzir o erro na determinação da degradabilidade.

\section{Conclusões}

A monensina pura para análise e o produto comercial Rumensin ${ }^{\circledR}$ tiveram maior efeito na redução da produção de amônia de fontes de proteína de maior degradabilidade.

Houve correlação estreita entre a produção de amônia e o pH, indicando que o abaixamento do $\mathrm{pH}$ ruminal reduz a atividade de desaminação.

A técnica de determinação da degradabilidade da proteína dos alimentos apresentou resultados satisfatórios somente para os alimentos protéicos, devido à maior quantidade de nitrogênio incubado em relação ao nitrogênio proveniente do meio de cultura, evitando o efeito adverso deste último na determinação.

\section{Referências Bibliográficas}

CHEN, G, RUSSELL, J.B. 1989. More monensin-sensitive, ammonia-producing bacteria from the rumen. Appl. Environ. Microbiol., 55:1052-1057.

CHANEY, A.L., MARBACH, E.P. 1962. Modified reagents for determination of urea and ammonia. Clin. Chem., 8:130-132.

CUNHA, L.T. Efeito da acidez e de ionóforos na degradação de proteínas por microrganismos ruminais. Viçosa: UFV, 1999. 68p. Dissertação (Mestrado em Zootecnia) - Universidade Federal de Viçosa, 1999.

CUNHA, L.T., LANA, R.P., BORGES, A.C. et al. 2000. The role of $\mathrm{pH}$ in regulating ammonia production by mixed ruminal bacteria. J. Anim. Sci., 78(Suppl. 1):289.

DINIUS, D.A., SIMPSON, M.E., MARSH, P.B. 1976. Effect of monensin fed with forage on digestion and the ruminal ecosystem of steers. J. Anim. Sci., 42:229-234.

DOMESCIK, E.J., MARTIN, S.A. 1997. Effects of laidlomycin propionate and monensin on the in vitro mixed ruminal microorganisms fermentation. J. Anim. Sci., 75 (Suppl. 1):257.

ERFLE, J.D., BOILA,R.J., TEATHER, R.M. et al. 1982. Effect of $\mathrm{pH}$ on fermentation characteristics and protein degradation by rumen microorganisms in vitro. J. Dairy Sci., 65:14571464.

GOODRICH, R.D., GARRETT, J.E., GAST, D.R. et al. 1984. Influence of monensin on the performance of cattle. J. Anim. Sci., 58:1484-1498.

HINO, T., RUSSELL, J.B. 1986. Relative contributions of ruminal bacteria and protozoa to the degradation of protein in vitro. J. Anim. Sci., 64:261-270.

LANA, R.P., RUSSELL, J.B. 1997. Effect of forage quality and monensin on the ruminal fermentation of fistulated cows fed 
1324 Rev. bras. zootec.

continuously at a constant intake. J. Anim. Sci., 75:224-229.

LANA, R.P., RUSSELL, J.B., VAN AMBURGH, M.E. 1998. The role of $\mathrm{pH}$ in regulating ruminal methane and ammonia production. J. Anim. Sci., 76:2190-2196.

LOWRY, O.H., ROSEBROUGH, N.J., FARR, A.L. et al. 1951. Protein measurement with the Folin phenol reagent. J. Biol. Chem., 193:265-275.

NEWBOLD, C.J., WALLACE, R.J., McKAIN, N. 1990. Effect of the ionophore tetronasin, on nitrogen metabolism of rumen microorganisms in vitro. J. Anim. Sci., 68:1103-1109.

NOLAN, J.V., NORTON, B.W., LENG, R.A. 1976. Further studies of the dynamics of nitrogen metabolism in sheep. $B r$. J. Nutr., 35:127-147.

RUSSELL, J.B. 1996. Bacteria: Mechanisms of ionophore action in ruminal bacteria. In: 1996 Scientific Update on Rumensin/ Tylan/ Micotil for the professional feedlot consultant. Indianapolis: Elanco Animal Health. p.E1-E19.

RUSSELL, J.B., MARTIN, S.A. 1984. Effects of various methane inhibitors on the fermentation of amino acids by mixed rumen micoorganisms in vitro. J. Anim. Sci., 59:1329-1338.

RUSSELL, J.B., O'CONNOR, J.D., FOX, D.G. et al. 1992. A net carbohydrate and protein system for evaluating cattle diets. I. Ruminal fermentation. J. Anim. Sci., 70:3551-3561.

RUSSELL, J.B., STROBEL, H.J. 1989. Mini-Review: The effect of ionophores on ruminal fermentation. Appl. Environ. Microbiol., 55:1-6.

RUSSELL, J.B., STROBEL, H.J., CHEN, G. 1988. The enrichment and isolation of a ruminal bacterium with a very high specific activity of ammonia production. Appl. Environ. Microbiol., 54:872-877.

RYAN, B.F., JOINER, B.L. 1994. Minitab handbook. 3.ed. Belmont, CA: Duxbury Press. 448p.

SATTER, L.D., SLYTER, L.L. 1974. Effect of ammonia concentration on rumen microbial protein production in vitro. Br. J. Nutr., 32:199-205.

STEEL, R.G.D., TORRIE, J.H. 1980. Principles and procedures of statistics: a biometrical approach. 2.ed. New York: McGraw-
Hill Publishing Co.

VAN NEVEL, C.J., DEMEYER, D.I. 1977. Effect of monensin on rumen metabolism in vitro. Appl. Environ.Microbiol., 34:251-257.

WALLACE, R.J. 1992. Gel filtration studies of peptide metabolism by rumen microorganisms. J. Sci. Food. Agric., 58:177-184.

WALLACE, R.J., ONODERA, R., COTTA, M.A. 1997. Metabolism of nitrogen-containing compounds. In: HOBSON, P.N., STEWART, C.S. (Ed.) The rumen microbial ecosystem. Londres: Blackie academic \& professional. 2.ed. p.283-328.

WHETSTONE, H.D., DAVIS, C.L., BRYANT, M.P. 1981. Effect of monensin on breakdown of protein by ruminal microorganisms in vitro. J. Anim. Sci., 53:803-809.

YECK, R.G., SMITH, L.W., CALVERT, C.C. Recovery of nutrients from animal wastes. An overview of existing options and potentials for use in feed. In: INT. SYMP. LIVEST. WASTES, 3, 1975, St. Joseph, MI. Proceedings... St. Joseph, MI: Am. Soc. Agric. Engineers, 1975. p.193-194.

Recebido em: 21/11/00

Aceito em: 07/03/00 